\title{
The osteoderm microstructure in doswelliids and proterochampsids and its implications for palaeobiology of stem archosaurs
}

\author{
Denis A. Ponce, Ignacio A. Cerda, Julia B. Desojo, and Sterling J. Nesbitt \\ Acta Palaeontologica Polonica 62 (4), 2017: 819-831 doi:https://doi.org/10.4202/app.00381.2017
}

Osteoderms are common in most archosauriform lineages, including basal forms, such as doswelliids and proterochampsids. In this survey, osteoderms of the doswelliids Doswellia kaltenbachi and Vancleavea campi, and proterochampsid Chanaresuchus bonapartei are examined to infer their palaeobiology, such as histogenesis, age estimation at death, development of external sculpturing, and palaeoecology. Doswelliid osteoderms have a trilaminar structure: two cortices of compact bone (external and basal) that enclose an internal core of cancellous bone. In contrast, Chanaresuchus bonapartei osteoderms are composed of entirely compact bone. The external ornamentation of Doswellia kaltenbachi is primarily formed and maintained by preferential bone growth. Conversely, a complex pattern of resorption and redeposition process is inferred in Archeopelta arborensis and Tarjadia ruthae. Vancleavea campi exhibits the highest degree of variation among doswelliids in its histogenesis (metaplasia), density and arrangement of vascularization and lack of sculpturing. The relatively high degree of compactness in the osteoderms of all the examined taxa is congruent with an aquatic or semi-aquatic lifestyle. In general, the osteoderm histology of doswelliids more closely resembles that of phytosaurs and pseudosuchians than that of proterochampsids.

Key words: Archosauria, Doswelliidae, Proterochampsidae, palaeoecology, microanatomy, histology, Triassic, USA.

Denis A. Ponce [denispunrn@yahoo.com.ar], Universidad Nacional de Río Negro, Estados Unidos 750, General Roca, 8332, Río Negro, Argentina. Ignacio A. Cerda [nachocerda6@yahoo.com.ar], Instituto de Investigación en Paleobiología y Geología (IIPG), Universidad Nacional de Río Negro, Av. Roca 1242, 8332, General Roca, Río Negro, Argentina; Museo “Carlos Ameghino", Belgrano 1700, Paraje Pichi Ruca (predio Marabunta), Cipolletti, 8324, Río Negro, Argentina. Julia B. Desojo [julideso@fcnym.unlp.edu.ar], División Paleontología Vertebrados, Museo de La Plata, Paseo del Bosque s/n, La Plata, B1900FWA, Buenos Aires, Argentina. Sterling J. Nesbitt [sjn2104@vt.edu], Department of Geosciences, Virginia Tech, Blacksburg, 24061, Virginia, USA. 
This is an open-access article distributed under the terms of the Creative Commons

Attribution License (for details please see creativecommons.org), which permits unrestricted use, distribution, and reproduction in any medium, provided the original author and source are credited.

FaF Full text $(1,391.9 \mathrm{kB})$ 